\title{
Researchers plan probe into Antarctic lakes
}

\section{Helen Gavaghan, Bologna}

The subglacial lakes of east Antarctica - the last great unexplored region on Earth could soon yield their secrets to science. An international group of researchers met in Bologna, Italy, last week to draft plans for a coordinated study of the region.

The Antarctic lakes lie beneath ice $4 \mathrm{~km}$ deep, and there are concerns that drilling into it might contaminate an environment that has been isolated from the rest of the world for millions of years. The Group of Specialists on Subglacial Antarctic Lake Exploration (GOS-SALE), which held the meeting, knows that its biggest challenge may be to convince conservationists that the project won't damage the environment.

Studying the lakes might resolve some major questions about the Earth's geological history, according to group member Ross Powell, a geologist at Northern Illinois University. And biologists are excited by the chance to study life forms from the isolated, subglacial ecosystem, says John Priscu of Montana State University, the group's chair.

The study might cost tens of millions of dollars, however, and the proposal is far from being accepted either by scientists or their political masters. Yet the presence in Bologna of key officials, such as Karl Erb, director of polar programmes at the US National Science Foundation, suggests that it has a good chance of coming to fruition.

Valery Lukin of the Russian Arctic and
Antarctic Research Institute used the forum to suggest extending an existing, 3.6-kmdeep borehole over the largest lake, Lake Vostok, that is already used to survey the Earth's climate history. Lukin invited international collaboration in the extension project, which would take samples of frozen water from above the lake but beneath the ice cap.

Recent data raise intriguing questions for further study. For example, Robin Bell, a geophysicist at the Lamont-Doherty Earth Observatory at Columbia University in New York, presented findings from a \$5-million survey of Lake Vostok, showing that the flow of ice across the lake is different from what had been anticipated. Bell also believes that the edge of the Antarctic continental shelf runs beneath Lake Vostok, rather than past the continent's western edge, as had been assumed.

Sergei Bulat of the St Petersburg Nuclear Physics Institute and Priscu presented DNA and microbial data, respectively, suggesting that life in Lake Vostok is widely dispersed, and may not be easily found by drilling into a single location.

While the US and Russian researchers concentrated on Lake Vostok, Italian scientists have studied the region around Concordia, a Franco-Italian base $600 \mathrm{~km}$ to the south. Ignazio Tabacco, a geophysicist at the University of Milan, provided evidence of a second large lake, and suggested that a string of other lakes in the area may be linked. The

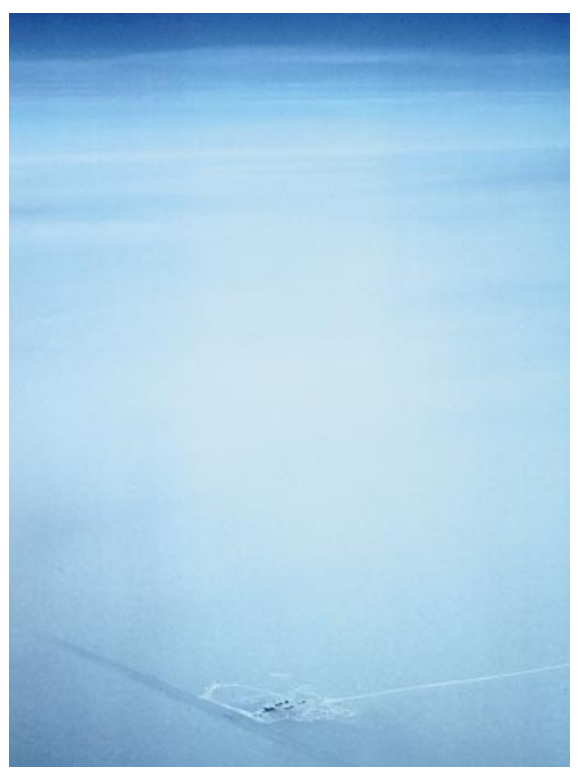

Ice house: the isolated Vostock station monitors the vast lake system underneath Antarctica's ice.

ultimate goal is to take samples from Lake Vostok, but there is some support for a plan to explore one of the other lakes first.

The meeting did not reach a firm plan, but officials believe that one will take shape soon. GOS-SALE intends to submit a research plan in July 2002 for endorsement by its parentbody, the Scientific Committee on Antarctic Research. Individual nations will then determine whether or not to participate.

\section{France boosts funding for biotechnology start-ups}

\section{Sally Goodman, Paris}

France has announced a plan to bolster its lagging biotechnology sector by injecting fresh public money into private biotech companies.

Presenting details of the plan to parliament last week, finance minister Laurent Fabius said that the government will provide 60 million euros (US\$54 million) next year for new biotechnology start-ups, and an additional 90 million euros in loan guarantees for more established companies.

Fabius hopes that the money, provided as part of the 2002 budget outlined by the Ministry of Finance in October, will be supplemented by the European Investment Bank. It will be invested in ventures that have already obtained some initial funding.

The government hopes that its actions will enable France to emulate Germany, which has doubled public investment in biotechnology over the past five years and taken over from Britain as Europe's leader in private biotechnology investment (see graph). France says it wants to overtake Germany by 2006.

"The announcement has generated a lot of enthusiasm in the industry," says Philippe Pouletty, president of France Biotech, an industry association that has been lobbying the government over what it regards as under-investment in biotechnology.

"The 2006 objective is realistic," says Thierry Laurent, an economist from the

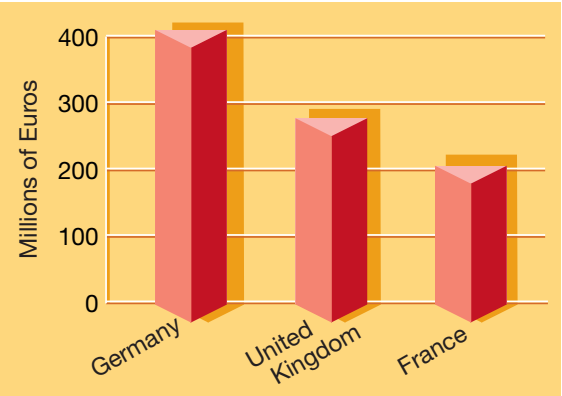

Mind the gap: in 2000, France lagged behind its rivals in private-sector biotech investment.
University of Évry-Val d'Esonne near Paris. But he says that other sources of investment, such as the national health insurance fund, need to be tapped if the objective is to be met.

The government hopes that the 90 million euros in guaranteed loans will leverage up to 450 million euros of private investment in French biotechnology companies.

Publicly funded research in life sciences, which receives a quarter of France's total research and development budget, stands to benefit indirectly through more technology transfer with the biotechnology companies. "This is an exceptional opportunity for the public sector,"says Bernard Pau, director of the biotechnology institute at the University of Montpellier.

The number of start-ups founded by academic researchers in all disciplines in France has increased fivefold since 1999, when a law was passed allowing publicly supported researchers to become shareholders in companies linked to their laboratories (see Nature 397, 187; 1999). 